Gazi University
Journal of Science
$\mathrm{http} / /$ dergipark.gov.tr/gujs

\title{
Estimation of Structural and Optical Parameters of (Mg, B) co-doped ZnO Nanoparticles
}

\author{
Ersin OZUGURLU* \\ Istanbul Technical University, Department of Mathematics, 34469, Maslak, Istanbul, Turkey
}

\section{Highlights}

- The sol-gel method was used to synthesize B-doped $\mathrm{Zn}_{0.98} \mathrm{Mg}_{0.02} \mathrm{O}$ nanoparticles.

- $\mathrm{ZnO}$ single phase was observed in the XRD analysis of all $\mathrm{B}$-doped $\mathrm{Zn}_{0.98} \mathrm{Mg}_{0.02} \mathrm{O}$ nanoparticles.

- The estimation of crystallite size, microstrain, and stress was done by the Williamson-Hall method.

- The maximum bandgap energy with a value of $3.28 \mathrm{eV}$ at $1 \% \mathrm{~B}$ concentration.

- The minimum dislocation density $\delta$ and Urbach energy $\mathrm{E}_{\mathrm{u}}$ were obtained at $1 \% \mathrm{~B}$ concentration.

\section{Article Info \\ Received:06 Sep 2020 Accepted:01 Dec 2020}

Keywords

\section{$\mathrm{ZnO}$}

Williamson-Hall

Stress

Refractive index

Urbach energy

\begin{abstract}
$\mathrm{Zn}_{0.98-\mathrm{x}} \mathrm{Mg}_{0.02} \mathrm{~B}_{\mathrm{x}} \mathrm{O}$ nanoparticles with various dopant ratios $(\mathrm{x}=0.00-0.05$ with increments of 0.01 ) were grown by using the sol-gel technique. The samples were synthesized and the $\mathrm{X}$-ray diffraction, scanning electron microscopy, optical reflectivity, and electron dispersive analyses were used to obtain the structural, electronic, and optical properties, respectively. WilliamsonHall procedure was utilized to obtain structural properties. The energy bandgap of the particles extracted from the absorption spectra was found to be ranging between $3.23 \mathrm{eV}$ and $3.28 \mathrm{eV}$ and decreasing with the boron concentration. The minimum dislocation density $\delta$ and Urbach energy $\mathrm{E}_{\mathrm{u}}$ and the maximum bandgap $\mathrm{E}_{\mathrm{g}}$ were obtained at $1 \% \mathrm{~B}$ concentration. The refractive index calculated by Moss's model was found to be 2.3 and the maximum bandgap energy with a value of $3.28 \mathrm{eV}$ suggests that these materials can be useful for infrared applications.
\end{abstract}

\section{INTRODUCTION}

Large binding and wide bandgap energies are important factors in semiconductors and their related industrial applications, therefore researchers focused on zinc oxide and zinc oxide-based devices [1-8]. Although $\mathrm{ZnO}$-based semiconductors show promise for many commercial and technological applications, it is observed that they still often do not perform as desired. To develop ZnO-based semiconductors, researchers have been trying various methods such as sol-gel, pulsed laser deposition (PLD), hydrothermal method, metal-organic chemical vapor deposition (MOCVD), and molecular beam epitaxy (MBE) [9-12]. Moreover, many studies are carried out to improve the physical, electrical, optical, magnetic, and mechanical properties of the final products (nanoparticle, thin-film, nanorod, etc.) by adding different elements (transition metals, rare earth elements) to $\mathrm{ZnO}$ depending on the area to be used. Therefore, it is essential to determine which elements should be doped into zinc oxide to increase the electronic, chemical, and physical properties. Many scientists have focused on the doping of transition and rare earth metals such as $\mathrm{B}, \mathrm{Mg}, \mathrm{Mn}, \mathrm{Ni}, \mathrm{Y}$, etc. into $\mathrm{ZnO}$ because of prospective applications such as varistors, spintronics, optoelectronics, cosmetics, and biomaterials [13-18]. With group III elements such as $\mathrm{B}, \mathrm{Al}, \mathrm{In}$ and $\mathrm{Ga}$, doping can effectively tune the bandgap of $\mathrm{ZnO}$, which affects the electrical, magnetic, mechanical, and optical properties of $\mathrm{ZnO}$ nanomaterials. Thus, Tsayn and Hsu [19] focused on boron-doped $\mathrm{ZnO}$. The 
Scherrer formula was used to calculate the crystallite sizes of the films. Due to distortion of the crystal lattice, for 5\% B concentration, the average crystallite sizes were reduced from 34.5 to $13.3 \mathrm{~nm}$. This alteration was initiated by the big variance between the ionic radii of $\mathrm{B}^{+3}(0.23 \AA)$ and $\mathrm{Zn}^{+2}(0.74 \AA)$. By using the hydrothermal method, Senol et al. [20] synthesized boron-doped $\mathrm{ZnO}$ within the range of 0.000.11 nanopowder samples to investigate the structural and mechanical properties. Parra et al. [21] used the simple solution method to blend two-dimensional boron-doped $\mathrm{ZnO}$ within the range of $0.00-0.05$ hexagonal nanodisks. They reported that $\mathrm{B}$-doped $\mathrm{ZnO}$ showed a better charge transport process as well as a charge storage capability. Using the Tauc plot in the DRS data, bandgap energy $\left(\mathrm{E}_{\mathrm{g}}\right)$ was evaluated, and the $\mathrm{E}_{\mathrm{g}}$ value for pure $\mathrm{ZnO}$ was found to be $3.25 \mathrm{eV}$, which progressively increased from 3.25 to $3.28 \mathrm{eV}$ for boron-doped $\mathrm{ZnO}$ within the range of 0.01-0.05 samples. Using the Burstein-Moss (B-M) effect of bandgap broadening, the deviation in Eg was analyzed. Moreover, they also showed that the $\mathrm{B}^{3+}$ ion substitution affected the crystallite size and lattice parameters. $\mathrm{Mg}$ doping into zinc oxide does not change the lattice constant due to both $\mathrm{Mg}$ and $\mathrm{Zn}$ atoms having similar radii and electronic shells. One of the main goals of the research is to produce the highest bandgap of the final product. Kilinc et al. [22] used the solgel technique to synthesize $\mathrm{Zn}_{1-\mathrm{x}} \mathrm{Mg}_{\mathrm{x}} \mathrm{O}$ ( $\mathrm{x}=0.01-0.3$ ) nanoparticles (NPs). The dc conductivities and the activation energies were obtained in the range of $10^{-9}-10^{-6} \mathrm{~S} / \mathrm{cm}$ at room temperature and $0.26-0.86 \mathrm{eV}$, respectively. Using the Scherrer formula, they calculated the average particle size values of $\mathrm{Zn}_{1-\mathrm{x}} \mathrm{Mg}_{\mathrm{x}} \mathrm{O}$ samples to be in the range of 22.43 to $29.72 \mathrm{~nm}$. In 2013, Arda et al. [23] showed that there was a decrease in bandgap to $3.7 \mathrm{eV}$ by doping $\mathrm{Mg}$ into $\mathrm{ZnO}$ materials by incorporation of $\mathrm{Al}$ although $\mathrm{Mg}$ doping increased bandgap of $\mathrm{ZnO}$, up to $\sim 4.05 \mathrm{eV}$ as demonstrated in Park et al. [24]. They used the sol-gel method for $\mathrm{Zn}, \mathrm{Mg}$, and $\mathrm{Al}$-based alkoxide to obtain $\mathrm{Zn}_{0.98-\mathrm{x}} \mathrm{Mg}_{\mathrm{x}} \mathrm{Al}_{0.02} \mathrm{O}$ solutions with various concentrations $(x=0.05,0.10,0.15$, and 0.20$)$. They found the particle sizes to be in the range of $80 \mathrm{~nm}$ to $100 \mathrm{~nm}$. Abed et al. [25] synthesized undoped and $\mathrm{Mg}$-doped $\mathrm{ZnO}$ nanocrystals using the sol-gel method and found average particle sizes to be in the range of $26.82 \mathrm{~nm}$ to $42.96 \mathrm{~nm}$ for various $\mathrm{Mg}$ concentrations $(1,2,3$, and $5 \%$ ). They discovered that $2 \% \mathrm{Mg}$ was the optimum value for an average particle size value of 42.96 $\mathrm{nm}$ and an energy bandgap value of $3.39 \mathrm{eV}$ by using the Tauc and Urbach methods. Abed et al. [25] showed that $\mathrm{Mg}$ doping into $\mathrm{ZnO}$ revealed a decrease of defect density in $\mathrm{ZnO}$ at low $\mathrm{Mg}$ doping by filling $\mathrm{Zn}$ vacancies. They summarized that this material could be valuable for the optoelectronic industry by altering the $\mathrm{Mg}$ contents in $\mathrm{ZnO}$. As mentioned above, separately, $\mathrm{Mg}$ and $\mathrm{B}$ doped $\mathrm{ZnO}$ (BZO, MgZO) have been extensively investigated recently due to their technical and industrial applications. Moreover, especially in the studies conducted in the literature, it is seen that the crystallite size, stress, and strain values found using the Scherrer formula are very empirical and not supported by solid theoretical grounding.

In this study, the sol-gel method was used for $\mathrm{Zn}_{0.98-\mathrm{x}} \mathrm{Mg}_{0.02} \mathrm{~B}_{\mathrm{x}} \mathrm{O}$ NPs and structural parameters were estimated by using different types of Williamson-Hall process for different dopant ratios $\mathrm{x}(\mathrm{x}=0.00-0.05$ with increments of 0.01) instead of using the Scherrer formula which does not deliver any information on the effect of strain in the crystal. This numerical approach was also investigated by different statistical tools. $\mathrm{Zn}_{0.98-\mathrm{x}} \mathrm{Mg}_{0.02} \mathrm{~B}_{\mathrm{x}} \mathrm{O}$ materials were systematically studied by considering the morphological and structural assets for various boron concentrations. Finite difference methods (FDMs) were used to calculate the Urbach energy values. Linear least-squares was used to determine the approximate bandgap energy values. Besides, the refractive index $(n>2)$ was calculated by three distinct models using these approximate bandgap energy values.

\section{EXPERIMENTAL}

\subsection{Preparation Process of $\mathrm{Zn}_{0.98-\mathrm{x}} \mathrm{Mg}_{0.02} \mathrm{~B}_{\mathrm{x}} \mathrm{O}$ Nanoparticles}

As a polycrystalline form, the sol-gel method was used to synthesize $\mathrm{Zn}_{0.98-\mathrm{x}} \mathrm{Mg}_{0.02} \mathrm{~B}_{\mathrm{x}} \mathrm{O}$ ( $\mathrm{x}=0.00-0.05$ with increments of 0.01) NPs. In this process, the precursor solutions were synthesized using Zinc acetate dihydrate $\left(\mathrm{Zn}\left(\mathrm{CH}_{3} \mathrm{CO}_{2}\right)_{2} \cdot 2 \mathrm{H}_{2} \mathrm{O}\right.$, Merck), Magnesium acetate tetrahydrate $\left(\mathrm{Mg}\left(\mathrm{CH}_{3} \mathrm{COO}\right)_{2} \cdot 4 \mathrm{H}_{2} \mathrm{O}\right)$, Alfa Aesar) and Boric acid $\left(\mathrm{H}_{3} \mathrm{BO}_{3}\right)$ Merck) without further purification. Boron doping was achieved by adding boric acid $\left(\mathrm{H}_{3} \mathrm{BO}_{3}\right)$ to the solution. The sol stabilizer was monoethanolamine (Merck) and HPLC grade methanol (Merck) was used as a solvent. The concentrations of precursor solutions $\left(\mathrm{Zn}\left(\mathrm{CH}_{3} \mathrm{COO}\right)_{2} \cdot 2 \mathrm{H}_{2} \mathrm{O}\right.$ 
and $\left.\mathrm{Mg}\left(\mathrm{CH}_{3} \mathrm{COO}\right)_{2} \cdot 4 \mathrm{H}_{2} \mathrm{O}\right)$ were prepared to be $0.25 \mathrm{~mol} / \mathrm{L}$ and then they were aged under magnetic stirring overnight. To form the gel phase, aging solutions were dried in the ambient atmosphere under magnetic stirring. Then the beaker is put in the ash furnace and retained at $400^{\circ} \mathrm{C}$ for 10 minutes to burn the organic material after all the solvent was evaporated then it is allowed to cool down in the furnace for 6 hours. Finally, it is kept at $600^{\circ} \mathrm{C}$ for 30 minutes to get the proper crystal orientation and after cooling in the furnace for 6 hours the nanoparticles are ready for the tests. The chemical kinetics of the reaction can be found in [8-9].

\subsection{Characterization Techniques}

The powder X-Ray diffraction measurement method (Rigaku diffractometer) was used to provide the mechanical phase definition for synthesized $\mathrm{Zn}_{0.98-\mathrm{x}} \mathrm{Mg}_{0.02} \mathrm{~B}_{\mathrm{x}} \mathrm{O}(\mathrm{x}=0.00-0.05$ with increments of 0.01$) \mathrm{NPs}$ and plotted in Figure 1. To obtain the XRD data, we used a Rigaku Multiflex diffractometer using $\mathrm{Cu} \mathrm{K \alpha}$ radiation $\left(\lambda=1.5408 \AA\right.$ ), in the scan range of $2 \theta$ between $20^{\circ}$ and $80^{\circ}$ with a scan speed of $3 \% \mathrm{~min}$ and with 0.02 as increments. To find out the microstructural properties, we examined the surface morphology images by operating Scanning Electron Microscope (SEM) tool (JEOL, JSM-5910LV model).

\section{RESULTS AND DISCUSSION}

\subsection{Structural Properties}

We used the sol-gel method to synthesize $\mathrm{Zn}_{0.98-\mathrm{x}} \mathrm{Mg}_{0.02} \mathrm{~B}_{\mathrm{x}} \mathrm{O}$ ( $\mathrm{x}=0.00$ - 0.05 with increments of 0.01) NPs, which were annealed at $600^{\circ} \mathrm{C}$ for 30 minutes under ambient atmosphere. As seen in Figure 1, all the patterns of $\mathrm{Zn}_{0.98-\mathrm{x}} \mathrm{Mg}_{0.02} \mathrm{~B}_{\mathrm{x}} \mathrm{O}$ NPs were procured as a $\mathrm{ZnO}$ single phase with the wurtzite hexagonal structure of the space group P63mc. X-ray diffraction data were used to obtain the (100), (002), (101), (102), (110), (103), (200), (112), (201), (004), and (202) diffraction planes of the $\mathrm{ZnO}$ hexagonal structure. These data are compatible with the ICDD data (Card number: 36-1451). Boron substitution did not change the structure of $\mathrm{ZnO}$. To investigate whether the system was slanted or not, the degree of alteration was evaluated using the equation:

$$
R=\frac{(2 a \sqrt{2 / 3})}{c},
$$

where $R$ is the degree of distortion; $a$ and $c$ are the lattice parameters given in Tables $1 \mathrm{a}-\mathrm{b}$. The values of $\mathrm{R}$ are approximately equal to 1 indicating that the system has no alteration as shown in Table $1 \mathrm{~b}$.

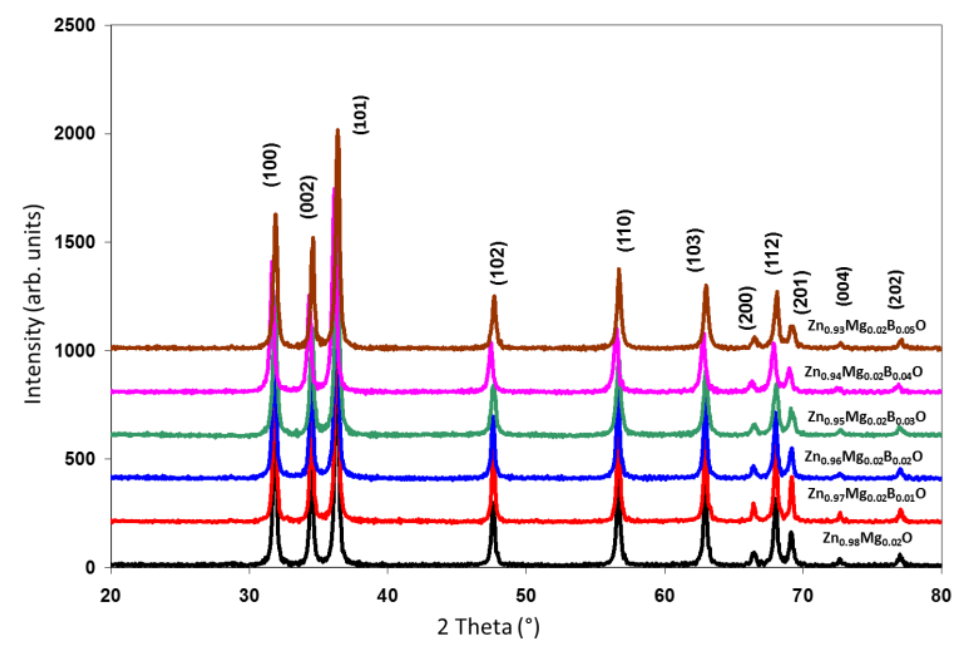


Figure 1. The XRD patterns of all $\mathrm{Zn}_{0.98-\mathrm{x}} \mathrm{Mg}_{0.02} \mathrm{~B}_{\mathrm{x}} \mathrm{O}(\mathrm{x}=0.00-0.05$ with increments of 0.01$)$ NPs

The atomic packing fraction (APF) is calculated with the following formula:

$$
A P F=\frac{2 \pi a}{3 \sqrt{3} c} .
$$

The calculated values of APF are displayed in Table $1 \mathrm{~b}$, the concentration of B content for the APF values is about $76 \%$. The detailed formulations of the parameters shown in Tables 1a-b can be found in [26]. The values of $D, c / a, V, R$, and $A P F s$ of $\mathrm{Zn}_{0.98-\mathrm{x}} \mathrm{Mg}_{0.02} \mathrm{~B}_{\mathrm{x}} \mathrm{O}$ (x=0.00 - 0.05 with increments of 0.01) NPs are given in Tables 1a-b. The concentration-dependent dislocation density $(\delta)$, and locality of the atoms and their displacement $(u)$ values became maximum and bond length turned into a minimum for the $\mathrm{Zn}_{0.93} \mathrm{Mg}_{0.02} \mathrm{~B}_{0.05} \mathrm{O}$ sample as observed in Table $1 \mathrm{~b}$. Table $1 \mathrm{~b}$ also illustrates the locality of the atoms and their displacements $(u)$ and they displayed nearly a stable behavior around 0.38 . The bond lengths $(L)$ were around $1.97 \mathrm{~nm}$ except at $\mathrm{x}=0.04$ where it reached a maximum value of $1.9857 \mathrm{~nm}$. Table 1a illustrates that for $4 \%$ B concentration, the maximum cell volume with a value of $48.2 \AA^{3}$ was obtained. The indication of a good crystallinity in $\mathrm{Zn}_{0.98-\mathrm{x}} \mathrm{Mg}_{0.02} \mathrm{~B}_{\mathrm{x}} \mathrm{O}$ samples can also be seen from the small $\delta$ values in Table $1 \mathrm{~b}$. However, as B concentration increases $\delta$ increases, which shows the quantity of the deficiencies in the crystal structure. The $\delta$ value was obtained at $1 \%$ B content.

\subsection{Williamson-Hall Method}

The Scherrer formula may be sufficient to estimate $D$ for the average crystallite size however, this procedure does not deliver data on the influence of strain. Moreover, there is an impact on line widening by $\varepsilon$ and $D$. Stokes and Wilson [27] found the following relation among the average strain, $\beta_{\mathrm{hkl}}$, and $\theta$

$$
\varepsilon=\frac{\beta_{\mathrm{hkl}}}{4 \tan (\theta)}
$$

where $\beta_{\mathrm{hkl}}$ is the full width at half maximum (FWHM) of the particular peak and $\theta$ is the Bragg's angle. It is always hard to distinguish the size and strain broadening present in XRD peaks. To distinct these two effects, the Williamson-Hall (W-H) method is used. Using the W-H, $\varepsilon, \sigma$, $\mathrm{u}$ and $D$ were approximated using three different models, to calculate $\varepsilon, \sigma, \mathrm{u}$, and $D$ : the UDEDM; to calculate $\varepsilon$ and $D$ : the UDM; to calculate $\varepsilon, \sigma$, and $D$ : the USDM. The isotropic environment of the crystal is taken into account in UDM, however, USDM and UDEDM presume the anisotropic nature. Thus, the values of $\varepsilon, \sigma$, and $D$ in the UDM are different than in USDM and UDEDM as illustrated in Table 2. The details of the above-mentioned methods were given in Mote et al. [28] and the data are presented in Table 2 and illustrated in Figures 2, 3, and 4. A linear least-squares method was used and the relative error was in the range of $10^{-12}$ to $10^{-7}$ and the statistical analysis is given in Section 3.3. In addition, $\varepsilon$ and $\sigma$ values are calculated by using the UDEDM, as shown in Table 2. Figure 5 displays $D$ values for various methods which are in consensus for $\mathrm{x}=1$ and $3 \%$. For the other concentrations, the average crystallite sizes attained from the Scherrer formula and $\mathrm{W}-\mathrm{H}$ analysis show a difference, this is due to the variation in averaging the crystallite size distribution. Tables 1,2 , and Figure 5 also illustrate that the crystallite size is proportional to stress and microstrain. All stress and microstrain values obtained by the W-H methods for $\mathrm{Zn}_{0.98-\mathrm{x}} \mathrm{Mg}_{0.02} \mathrm{~B}_{\mathrm{x}} \mathrm{O}$ ( $\mathrm{x}=0.00$ - 0.05 with increments of 0.01) NPs are shown in Table 2 and both values increase as B concentration increases. Mallika et al. [29] also used the sol-gel method to synthesize $\mathrm{Mg}$-doped $\mathrm{ZnO}$ NPs and they reported on structural and optical properties using the $\mathrm{W}-\mathrm{H}$ method. They illustrated that an increase in $\mathrm{Mg}$ concentration resulted in a decrease in the particle size of $\mathrm{ZnO}$. They also observed the absorption spectrum of the $\mathrm{ZnO}$ blue shift as 
the $\mathrm{Mg}$ concentration enriched from $1 \mathrm{~mol} \%$ to $5 \mathrm{~mol} \%$, probably because of a decrease in particle size. There was no formation of a $\mathrm{MgO}$ secondary phase above the solid solubility limit of $\mathrm{Mg}$ in $\mathrm{ZnO}$. Mallika et al. [29] considered only the UDM by plotting $\beta \cos (\theta) / \lambda$ vs. $4 \sin (\theta) / \lambda$ instead of plotting of $\beta \cos (\theta)$ vs. $4 \sin (\theta)$, thus our data is different. We discuss this in Section 3.3. To characterize the crystal perfection, these models are greatly desirable with a certain accuracy.

Table 1a. The unit cell volume (V), crystallite size $(D)$, lattice parameters a and c, cla ratio in the $Z n_{0.98-}$ ${ }_{x} \mathrm{Mg}_{0.02} B_{x} O(x=0.00-0.05$ with increments of 0.01$) N P s$

\begin{tabular}{|l|l|l|l|l|l|}
\hline $\mathrm{x}$ & $\mathrm{D}(\mathrm{nm})$ & $\mathrm{a}(\AA)$ & $\mathrm{c}(\AA)$ & $\mathrm{c} / \mathrm{a}$ & $\mathrm{V}\left(\AA^{3}\right)$ \\
\hline 0 & 28.44 & 3.24 & 5.20 & 1.603 & 47.338 \\
\hline 1 & 32.79 & 3.24 & 5.19 & 1.601 & 47.284 \\
\hline 2 & 27.41 & 3.24 & 5.20 & 1.601 & 47.372 \\
\hline 3 & 24.87 & 3.24 & 5.19 & 1.601 & 47.199 \\
\hline 4 & 24.59 & 3.26 & 5.22 & 1.599 & 48.192 \\
\hline 5 & 23.89 & 3.24 & 5.18 & 1.600 & 47.061 \\
\hline
\end{tabular}

Table $1 \boldsymbol{b}$. The degree of distortion $(R)$, the atomic packing fraction (APF), the dislocation density $(\delta)($ the amount of defect in the sample), the locality of the atoms and their displacement $(u)$, and bond length $(L)$ in the $\mathrm{Zn}_{0.98-x} \mathrm{Mg}_{0.02} \mathrm{~B}_{x} \mathrm{O}$ ( $x=0.00$ - 0.05 with increments of 0.01$) \mathrm{NPs}$

\begin{tabular}{|l|l|l|l|l|l|}
\hline $\mathrm{x}$ & $\mathrm{R}$ & $\mathrm{APF}$ & $\delta\left(\mathrm{nm}^{-2}\right)$ & $\mathrm{u}$ & $\mathrm{L}(\AA)$ \\
\hline 0 & 1.019 & 0.75 & 0.0012 & 0.3797 & 1.9739 \\
\hline 1 & 1.020 & 0.76 & 0.0009 & 0.3800 & 1.9732 \\
\hline 2 & 1.020 & 0.76 & 0.0013 & 0.3800 & 1.9744 \\
\hline 3 & 1.020 & 0.76 & 0.0016 & 0.3800 & 1.9720 \\
\hline 4 & 1.021 & 0.76 & 0.0017 & 0.3803 & 1.9857 \\
\hline 5 & 1.021 & 0.76 & 0.0018 & 0.3803 & 1.9701 \\
\hline
\end{tabular}

\subsection{Statistical Analysis}

The MATLAB function fitlm was used to determine how well the linear least-squares model was and some statistical tools were used to demonstrate how the model approximates are similar to the observed data and presented in Tables 3-5 for each model. We can say that the UDEDM gives a good fit for 2\% B concentration comparing to the other models since $R^{2}$ is nearly 1 . For $2 \% \mathrm{~B}$ concentration, the USDM and 
UDEDM models indicate a good agreement since the correlation coefficients are bigger than 0.9. These remarks can still mislead us. We also have to analyze our linear model versus the constant model by using the F-statistic. The important parameter for the F-statistic is the $p$-value. We can see from Tables 3-5 that the excellent result is for $2 \% \mathrm{~B}$ concentration in UDEDM since the p-value was 0.0217 .

Table 2. Structural parameters: $D(\mathrm{~nm}), \varepsilon\left(\times 10^{-4}\right), \sigma\left(\mathrm{N} / \mathrm{m}^{2}\right)\left(\mathrm{x} 10^{6}\right)$, and $u\left(\mathrm{x} 10^{3}\right)$ in the $\mathrm{Zn} n_{0.98-x} M g_{0.02} B_{x} O$ ( $x=0.00-0.05$ with increments of 0.01) NPs. using three different models based on the W-H method, namely, the UDM, USDM, and UDEDM

\begin{tabular}{|c|c|c|c|c|c|c|c|c|c|}
\hline & \multicolumn{9}{|c|}{ The Williamson-Hall Method } \\
\hline$x$ & \multicolumn{2}{|l|}{ UDM } & \multicolumn{3}{|c|}{ USDM } & \multicolumn{4}{|c|}{ UDEDM } \\
\hline$\%$ & $\mathrm{D}$ & $\varepsilon$ & $\mathrm{D}$ & $\sigma$ & $\varepsilon_{\text {ave }}$ & $\mathrm{D}$ & $\mathrm{u}$ & $\sigma_{\text {ave }}$ & $\varepsilon_{\text {ave }}$ \\
\hline $\mathbf{0}$ & 28.00 & -1.3 & 31.54 & 41.51 & 3.31 & 32.35 & 11.48 & 50.06 & 4.28 \\
\hline 1 & 33.13 & 0.58 & 31.74 & -12 & -0.95 & 31.53 & 0.91 & -14.09 & -1.20 \\
\hline 2 & 38.13 & 6.65 & 33.58 & 30.32 & 2.42 & 35.14 & 10 & 46.72 & 3.99 \\
\hline 3 & 24.41 & 1.02 & 24.00 & 2.54 & 0.2 & 24.09 & 0.09 & 4.52 & 0.39 \\
\hline 4 & 38.77 & 14.51 & 35.02 & 138 & 11 & 41.43 & 167.3 & 191.1 & 16.34 \\
\hline 5 & 31.14 & 6.89 & 38.85 & 177 & 14.09 & 47.37 & 242.5 & 230.1 & 19.67 \\
\hline
\end{tabular}
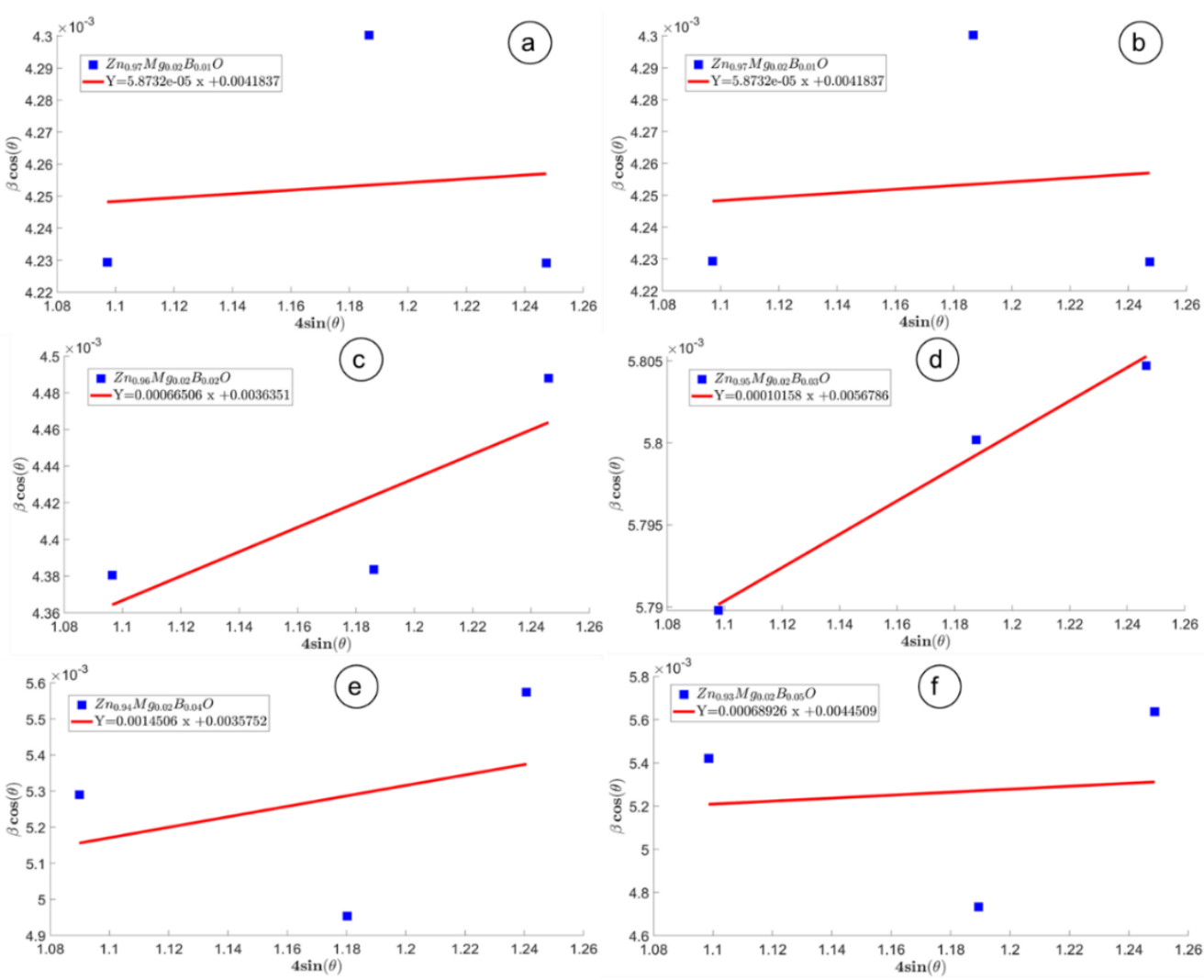
Figure 2. Plot of $\beta \cos (\theta)$ vs. $4 \sin (\theta)$ for $Z n_{0.98-x} M g_{0.02} B_{x} O$ : (a) $x=0.00$, (b) $x=0.01$, (c) $x=0.02$, (d) $x=0.03,(e) x=0.04$, and $(f) x=0.05$
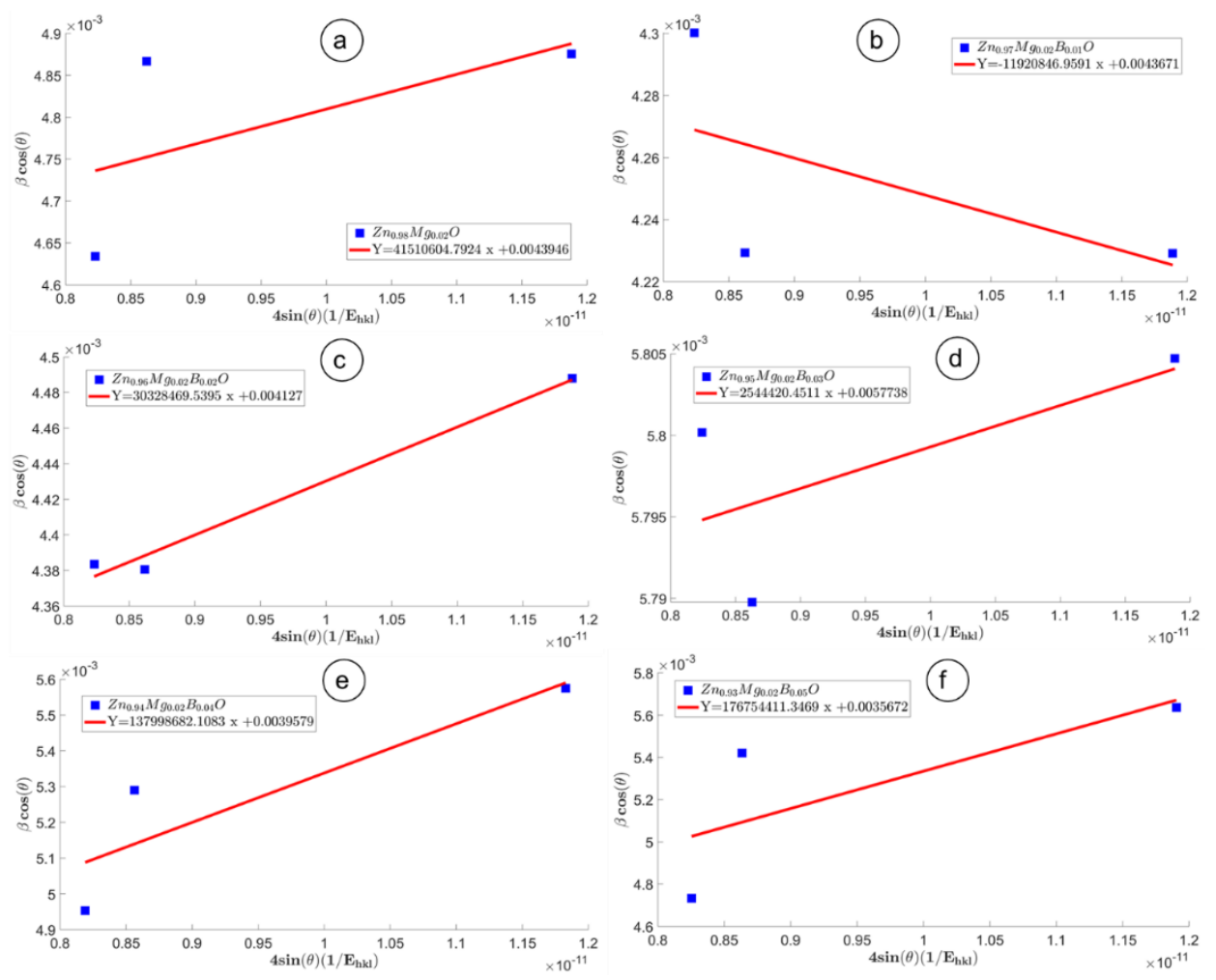

Figure 3. The plot of $\beta \cos (\theta)$ vs. $4 \sin (\theta)\left(1 / E_{h k l}\right)$ : (a) $Z n_{0.98} M g_{0.02} O$, (b) $Z n_{0.97} M_{0.02} B_{0.01} O$, (c) $Z n_{0.96} M g_{0.02} B_{0.02} O$, (d) $Z n_{0.95} M g_{0.02} B_{0.03} O$, (e) $Z n_{0.94} M g_{0.02} B_{0.04} O$, and (f) $Z n_{0.93} M_{0.02} B_{0.05} O$
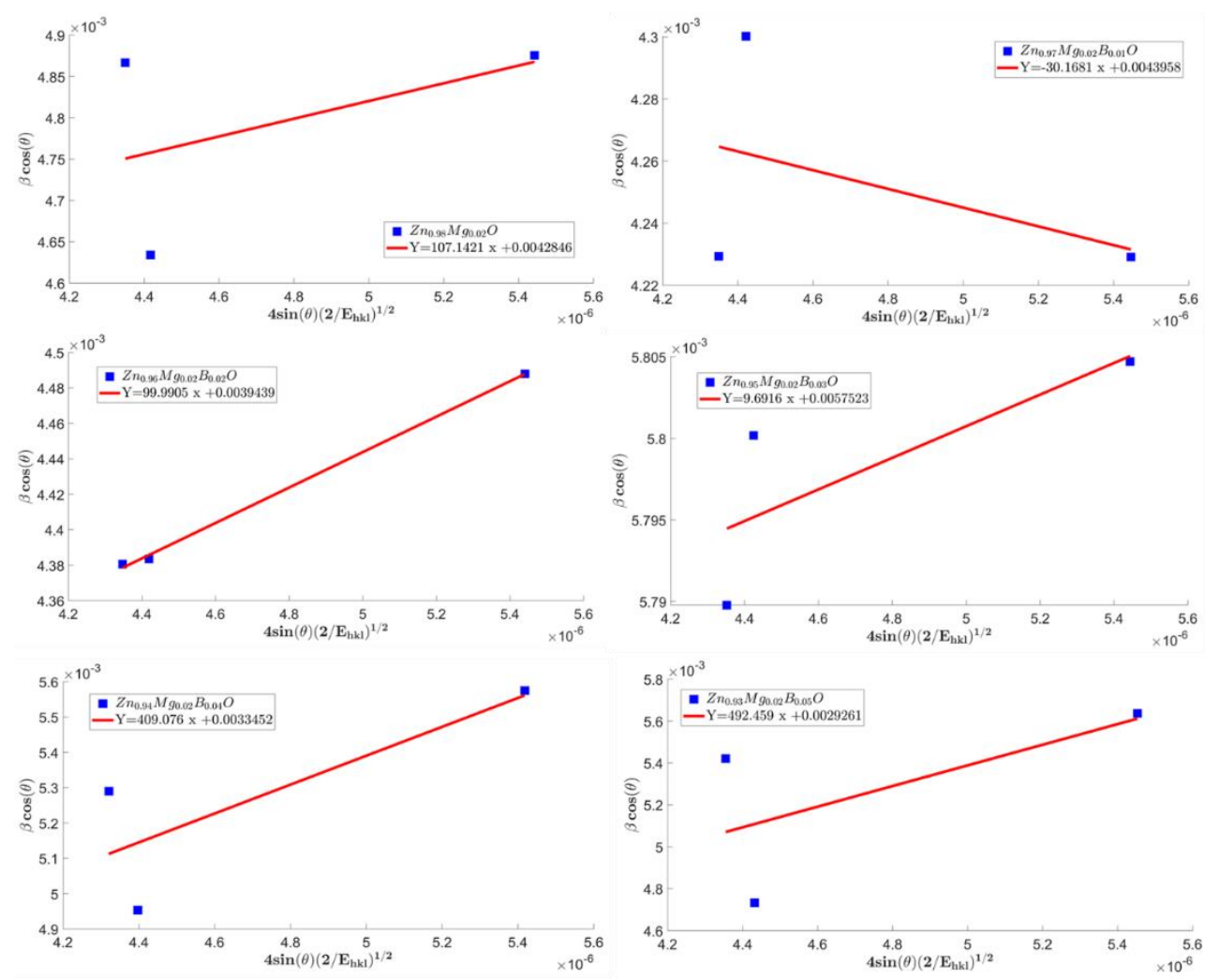
Figure 4. Left to right, top to bottom. The plot of $\beta \cos (\theta)$ vs. $4 \sin (\theta) \sqrt{2 / E_{h k l}}(a) Z_{0.98} M g_{0.02} O$, (b) $Z n_{0.97} M_{0.02} B_{0.01} O$, (c) $\mathrm{Zn}_{0.96} \mathrm{Mg}_{0.02} \mathrm{~B}_{0.02} \mathrm{O}$, (d) $\mathrm{Zn}_{0.95} \mathrm{Mg}_{0.02} \mathrm{~B}_{0.03} \mathrm{O}$, (e) $\mathrm{Zn}_{0.94} \mathrm{Mg}_{0.02} \mathrm{~B}_{0.04} \mathrm{O}$, and (f) $\mathrm{Zn}_{0.93} \mathrm{Mg}_{0.02} \mathrm{~B}_{0.05} \mathrm{O}$

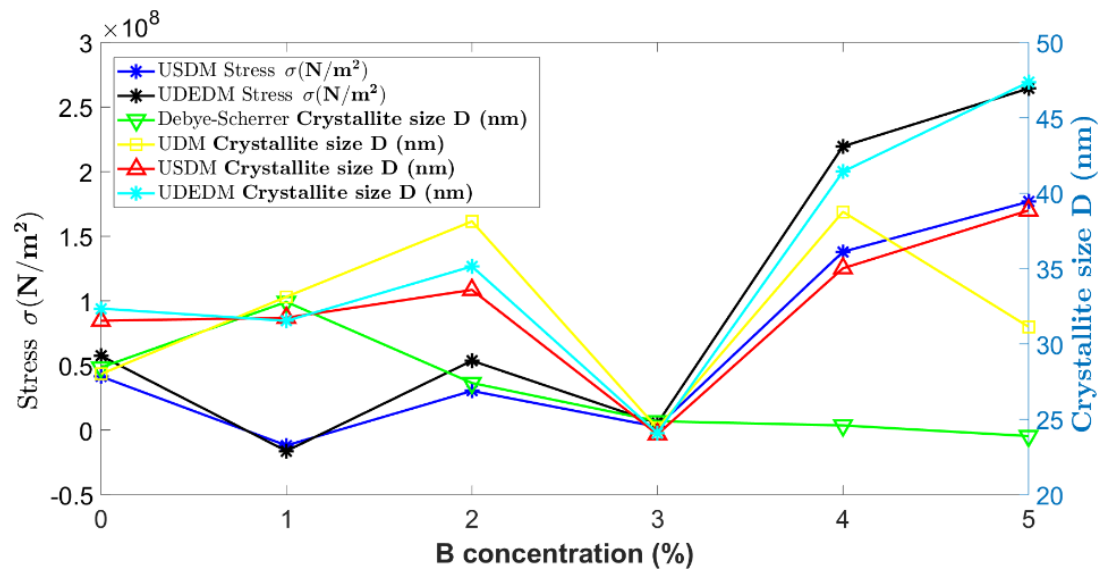

Figure 5. The crystallite size and the maximum stress $(\sigma)$ with the UDEDM for $Z_{0.98-x} M_{0.02} B_{x} O(x=0.00$ - 0.05 with increments of 0.01$) \mathrm{NPs}$

Table 3. Coefficient of determination $\left(R^{2}\right)$, the root mean squared error (RMSE), the sum of the squared total (SST), the correlation coefficient, and p-value for F-statistic vs. constant model

\begin{tabular}{|l|c|l|l|l|l|}
\hline \multirow{2}{*}{\begin{tabular}{l} 
Conc. \\
\cline { 2 - 6 }
\end{tabular}} & \multicolumn{6}{|l|}{ UDM } & $\begin{array}{l}\text { RMSE } \\
\left(\mathrm{x} \mathrm{10} 0^{-5}\right)\end{array}$ & $\begin{array}{l}\text { SST } \\
\left(\mathrm{x} \mathrm{10} 0^{-8}\right)\end{array}$ & $\begin{array}{l}\text { Corr. } \\
\text { coeff. }\end{array}$ & $p$-value \\
\hline 0 & 0.0054 & 1.93 & 3 & 0.0736 & 0.9531 \\
\hline 1 & 0.0117 & 5.7 & 0.3 & 0.1082 & 0.9310 \\
\hline 2 & 0.6691 & 4.9 & 0.7 & 0.8180 & 0.3902 \\
\hline 3 & 0.9889 & 0.1 & 0.01 & 0.9944 & 0.0673 \\
\hline 4 & 0.1253 & 4.1 & 19.3 & 0.3540 & 0.7696 \\
\hline 5 & 0.0122 & 6.6 & 44.6 & 0.1104 & 0.9296 \\
\hline
\end{tabular}

Table 4. Coefficient of determination $\left(R^{2}\right)$, the root mean squared error (RMSE), the sum of the squared total (SST), the correlation coefficient, and p-value for F-statistic vs. constant model

\begin{tabular}{|l|l|l|l|l|l|}
\hline $\begin{array}{l}(\%) \\
\text { Conc. }\end{array}$ & \multicolumn{6}{|l|}{$R^{2}$} & $\begin{array}{l}\text { UMSE } \\
\left(\times 10^{-5}\right)\end{array}$ & $\begin{array}{l}\text { SST } \\
\left(\times 10^{-8}\right)\end{array}$ & $\begin{array}{l}\text { Corr. } \\
\text { coeff. }\end{array}$ & $p$-value \\
\hline 0 & 0.3692 & 1.5 & 3.7 & 0.6076 & 0.5843 \\
\hline 1 & 0.3403 & 4.7 & 0.3 & 0.5833 & 0.6035 \\
\hline 2 & 0.9854 & 1.0 & 0.7 & 0.9927 & 0.0770 \\
\hline 3 & 0.4423 & 0.8 & 0.01 & 0.6650 & 0.5368 \\
\hline 4 & 0.7881 & 2.0 & 19.3 & 0.8877 & 0.3046 \\
\hline 5 & 0.5642 & 4.4 & 44.6 & 0.7511 & 0.4590 \\
\hline
\end{tabular}

Table 5. Coefficient of determination $\left(R^{2}\right)$, the root mean squared error (RMSE), the sum of the squared total (SST), the correlation coefficient, and $p$-value for F-statistic vs. constant model

\begin{tabular}{|l|c|l|l|l|l|}
\hline \multicolumn{5}{|c|}{ UDEDM } \\
\hline $\begin{array}{l}(\%) \\
\text { Conc. }\end{array}$ & $R^{2}$ & $\begin{array}{l}\text { RMSE } \\
\left(\mathrm{x} 10^{-5}\right)\end{array}$ & $\begin{array}{l}\text { SST } \\
\left(\mathrm{x} 10^{-8}\right)\end{array}$ & $\begin{array}{l}\text { Corr. } \\
\text { coeff. }\end{array}$ & $p$-value \\
\hline 0 & 0.2296 & 1.7 & 3.7 & 0.4792 & 0.6819 \\
\hline 1 & 0.2035 & 5.1 & 0.3 & 0.4511 & 0.7021 \\
\hline 2 & 0.9988 & 0.2 & 0.79 & 0.9994 & $\mathbf{0 . 0 2 1 7}$ \\
\hline
\end{tabular}




\begin{tabular}{|l|l|l|l|l|l|}
\hline 3 & 0.5970 & 0.6 & 0.01 & 0.7726 & 0.4379 \\
\hline 4 & 0.6489 & 2.6 & 19.3 & 0.8055 & 0.4038 \\
\hline 5 & 0.4083 & 5.1 & 44.6 & 0.6389 & 0.5587 \\
\hline
\end{tabular}

\subsection{Morphology Characteristics of $\mathrm{Zn}_{0.98-\mathrm{x}} \mathrm{Mg}_{0.02} \mathrm{~B}_{\mathrm{x}} \mathrm{O} \mathrm{NPs}$}

The morphology of all $\mathrm{Zn}_{0.98-\mathrm{x}} \mathrm{Mg}_{0.02} \mathrm{~B}_{\mathrm{x}} \mathrm{O}$ ( $\mathrm{x}=0.00-0.05$ with increments of 0.01 ) NPs were analyzed by the SEM technique in the range of $1 \mu \mathrm{m}$ magnifications. Figure 6 displays SEM images and the EDX graph of $\mathrm{Zn}_{0.97} \mathrm{Mg}_{0.02} \mathrm{~B}_{0.01} \mathrm{O}$ compositions for $2 \mu \mathrm{m}$ (a), $100 \mathrm{~nm}$ (b), and (c), respectively. A casual particle spreading has occurred and the distribution of particles is conquered by particle assembly, as displayed in Figures 6(a-c). Figures 6(c) - 10(c) exhibit EDX figures indicating the diagram and essential composites of all $\mathrm{Zn}_{0.98-\mathrm{x}} \mathrm{Mg}_{0.02} \mathrm{~B}_{\mathrm{x}} \mathrm{O}$ NPs, respectively. The peaks of all proposed structures are indicated in the EDX analysis, which shows how well the materials are prepared.

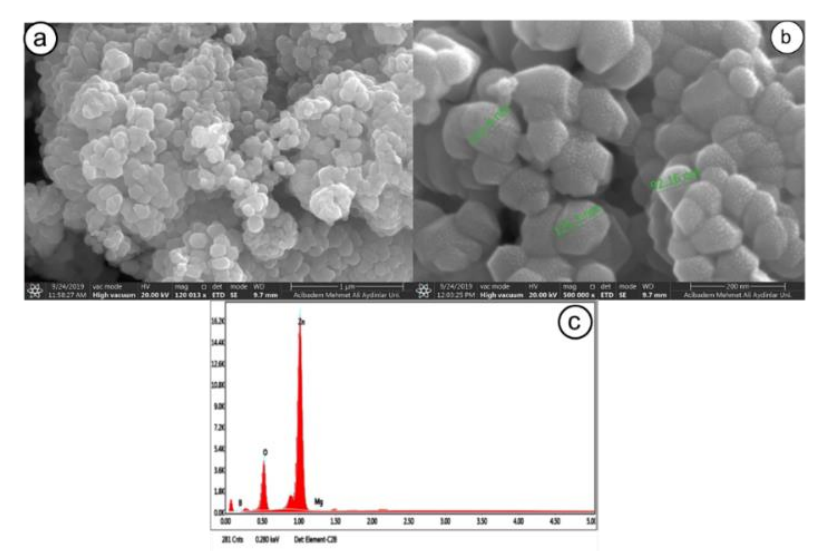

Figure 6. SEM images and the EDX graph of $\mathrm{Zn}_{0.97} \mathrm{Mg}_{0.02} \mathrm{~B}_{0.01} O$ composition for $2 \mu \mathrm{m}(\mathrm{a}), 100 \mathrm{~nm}(\mathrm{~b})$, and $(c)$, respectively
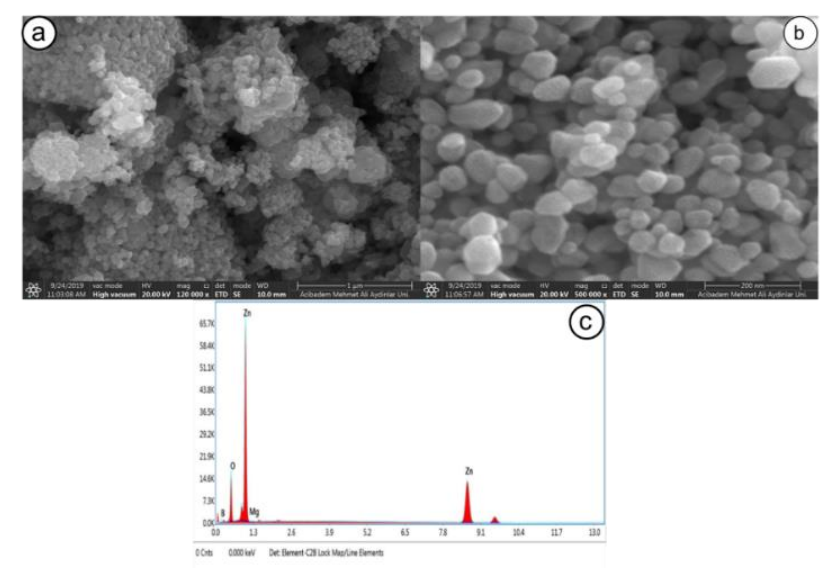

Figure 7. SEM images and the EDX graph of $\mathrm{Zn}_{0.96} \mathrm{Mg}_{0.02} \mathrm{~B}_{0.02} \mathrm{O}$ composition for $2 \mu \mathrm{m}(\mathrm{a}), 100 \mathrm{~nm}(\mathrm{~b})$, and $(c)$, respectively 


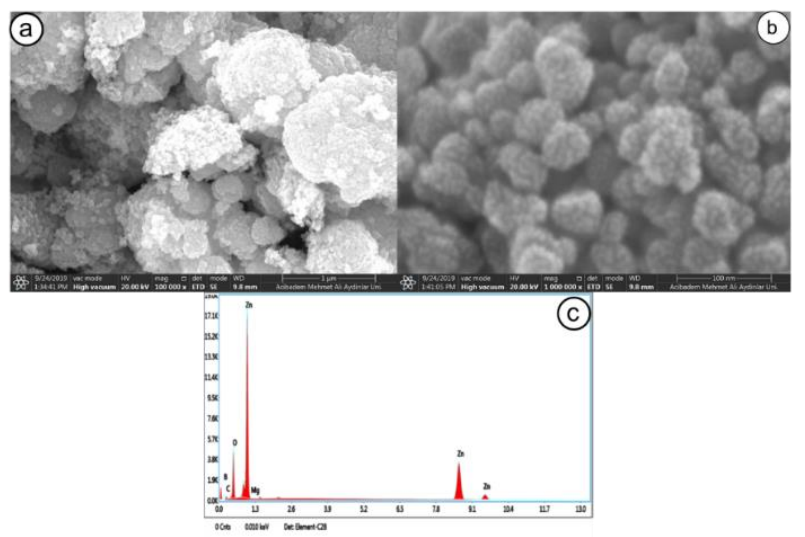

Figure 8. SEM images and the EDX graph of $Z n_{0.95} M_{0.02} B_{0.03} O$ composition for $2 \mu \mathrm{m}(a), 100 \mathrm{~nm}$ (b), and $(c)$, respectively

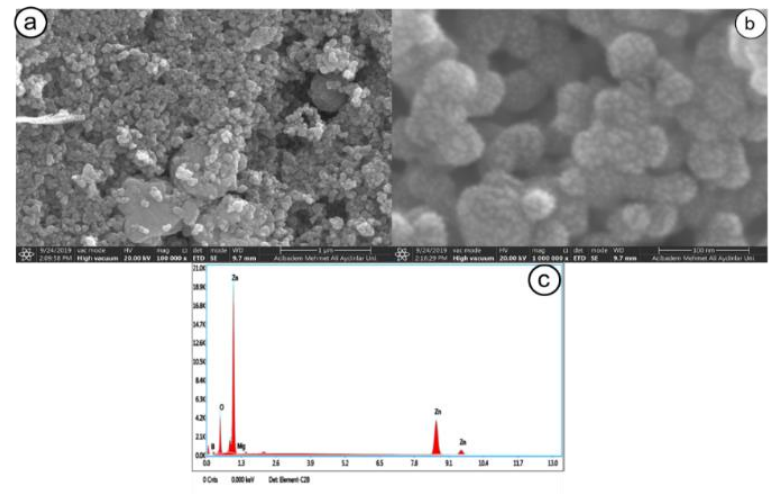

Figure 9. SEM images and the EDX graph of $Z n_{0.94} M_{0.02} B_{0.04} O$ composition for $2 \mu \mathrm{m}(a), 100 \mathrm{~nm}(\mathrm{~b})$, and $(c)$, respectively

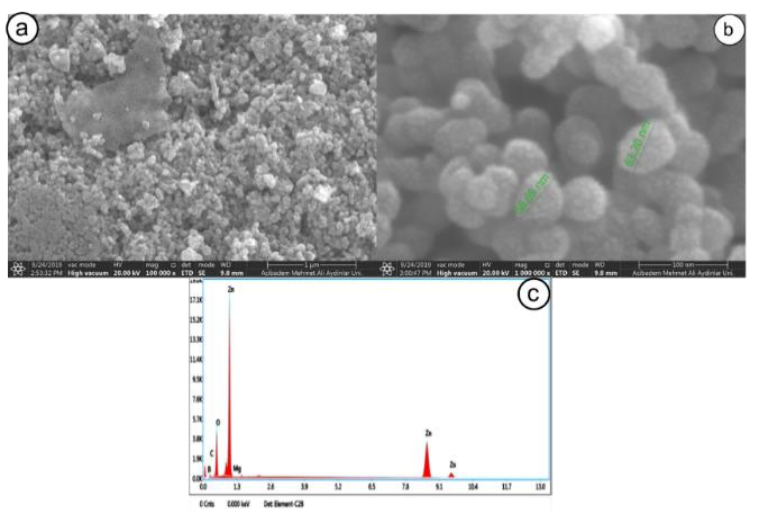

Figure 10. SEM images and the EDX graph of $Z n_{0.93} M_{0.02} B_{0.05} O$ composition for $2 \mu \mathrm{m}(a), 100 \mathrm{~nm}$ (b), and $(c)$, respectively 


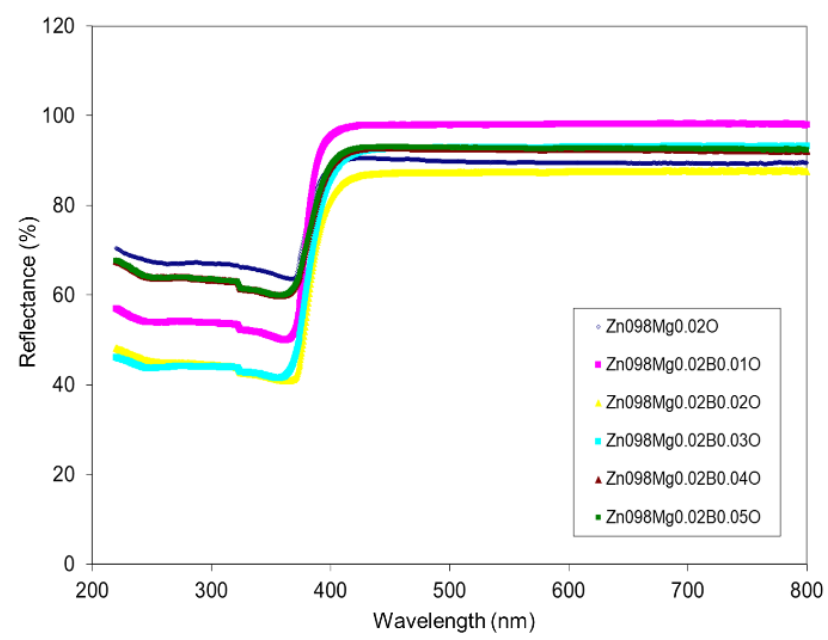

Figure 11. The reflectance spectra of $Z n_{0.98-x} M_{0.02} B_{x} O$ NPs at different $B$ concentrations

\subsection{Optical Analysis}

UV-VIS diffuse reflectance measurements (DRS) were used to obtain the reflectance spectra of the $\mathrm{Zn}_{0.98-\mathrm{x}} \mathrm{Mg}_{0.02} \mathrm{~B}_{\mathrm{x}} \mathrm{O}$ ( $\mathrm{x}=0.00-0.05$ with increments of 0.01 ) NPs in the range of 220-800 nm wavelength, as shown in Figure 11. An absorption edge appeared in all the reflectance spectra nearby $365 \mathrm{~nm}$ wavelength which were analogous for the bandgap of $\mathrm{ZnO}$. For $\mathrm{Zn}_{0.97} \mathrm{Mg}_{0.02} \mathrm{~B}_{0.01} \mathrm{O}$ NPs, the maximum reflectance was observed. The optical bandgap energy and absorption coefficient are related to each other with the following equation:

$$
(\alpha h v)^{1 / n}=\mathrm{k}\left(\mathrm{h} v-E_{g}\right)
$$

where $E_{g}$ is the optical bandgap energy, $\alpha$ is the absorption coefficient, $h v$ is the photon energy, and $k$ is the energy-independent constant [15]. $n$ is taken as $1 / 2$ for direct bandgap semiconductors. Thus, Equation (4) can be written as

$$
\mathrm{F}\left(\mathrm{R} \_\alpha\right) \mathrm{h} v=\mathrm{k}\left(\mathrm{h} v-E_{g}\right)^{1 / 2} .
$$

The slope of the graph of $\left(F\left(R_{x}\right) h v\right)^{2}$ was approximated by the linear regression function $y(h v)=A \times h v+$ $B$ accurate within two decimal digits for bandgap energies of $\mathrm{B}$-doped $\mathrm{ZnMg}_{0.02} \mathrm{O}$ NPs in the range of 3.23 to $3.28 \mathrm{eV}$ between 350 and $400 \mathrm{~nm}$ wavelength as illustrated in Figure 12 [15] and optimized $A$, $B$, and the corresponding relative errors are depicted in Table 6 . These changes in the values of $E_{g}$ might be affected by several factors such as the size effect of the dopant metals, lattice parameters, crystallite size, and carrier concentration in $\mathrm{ZnO}$ lattice [29]. As B concentrations increased, there was a decrease in the bandgap, which points out that the incorporation of $\mathrm{B}$ ions into $\mathrm{ZnMgO}$ lattice exposes new electronics states in the energy bandgap as illustrated in Figure 13 in which a second-order polynomial fit was used. There is a broadening of the optical bandgap with the increase of boron (B ) concentration up to 1\%. This may be attributed to either the Moss-Burstein shift as stated in Pawar et al. [30] and Kerli et al. [31] or the quantum confinement effect as claimed by Bhattacharjee et al [32]. Between $1 \%$ and 3\% B concentrations, the bandgap values fluctuated. For $3 \%$ and higher B concentration, the bandgap energy is inversely proportional to the crystallite size, stress, and microstrain as illustrated in Tables 2 and 6 and there is a decrease of $E_{g}$ which occurs owing to increasing carrier concentration as a consequence of extra electron delivered by replacement of $\mathrm{B}^{+3}$ atom with host $\mathrm{Zn}^{+2}$ atom (also known as shrinkage effect) as reported in Hurma [33]. 
Tables 1a and 6 illustrate that the energy bandgap is inversely proportional to cell volume. For $1 \% \mathrm{~B}$ concentration, the maximum bandgap was obtained with a value of $3.28 \mathrm{eV}$. Figure 12 and Tables 2 and 6 also illustrate that the energy bandgap is inversely proportional to crystallite size, strain, and stress, respectively. We also plot the stress $(\sigma)$ with the USDM and the maximum stress $(\sigma)$ with the UDEDM and the microstrain $(\varepsilon)$ with the UDM, the maximum microstrains $(\varepsilon)$ with the USDM and UDEDM with various B concentrations in Figures 13 and 14. Both stress $(\sigma)$ and microstrain $(\varepsilon)$ increase as boron concentration increase as illustrated in Figure 13. Figure 15 exhibits crystallite sizes $D(\mathrm{~nm})$ with the Debye-Scherrer and other Williamson-Hall methods.

Table 6. For different $B$ doping ratios for the $Z n_{0.98-x} M_{0.02} B_{x} O$ ( $x=0.00-0.05$ with increments of 0.01) $N P$ s: the linear least-squares function $y(h v)=A \times h v+B$, bandgap energies $E_{g}(\mathrm{eV})$, and relative errors

\begin{tabular}{|l|l|l|l|l|}
\hline Sample Name & $\mathrm{A}$ & $\mathrm{B}$ & $\mathrm{E}_{\mathrm{g}}(\mathrm{eV})$ & Rel. Error \\
\hline $\mathrm{Zn}_{0.99} \mathrm{Mg}_{0.02} \mathrm{O}$ & 2.33 & -7.64 & 3.27 & $7.1 \times 10^{-6}$ \\
\hline $\mathrm{Zn}_{0.97} \mathrm{Mg}_{0.02} \mathrm{~B}_{0.01} \mathrm{O}$ & 6.76 & -22.20 & 3.28 & $3.7 \times 10^{-4}$ \\
\hline $\mathrm{Zn}_{0.96} \mathrm{Mg}_{0.02} \mathrm{~B}_{0.02} \mathrm{O}$ & 20.12 & -65.39 & 3.25 & $1.4 \times 10^{-4}$ \\
\hline $\mathrm{Zn}_{0.95} \mathrm{Mg}_{0.02} \mathrm{~B}_{0.03} \mathrm{O}$ & 13.41 & -43.82 & 3.27 & $5.8 \times 10^{-5}$ \\
\hline $\mathrm{Zn}_{0.94} \mathrm{Mg}_{0.02} \mathrm{~B}_{0.04} \mathrm{O}$ & 1.37 & -4.43 & 3.24 & $2.5 \times 10^{-4}$ \\
\hline $\mathrm{Zn}_{0.93} \mathrm{Mg}_{0.02} \mathrm{~B}_{0.05} \mathrm{O}$ & 1.32 & -4.28 & 3.23 & $5.8 \times 10^{-4}$ \\
\hline
\end{tabular}

The main purposes of the recent research are to obtain a wide bandgap $E_{g}$ and a high refractive index $n$ because of their implementations in sensor industries and related fields. It is recognized that in semiconductor materials, the refractive index is crucial for characterizing optical properties and is inversely proportional to the optical bandgap. Materials are transparent in the visible region if their refractive indices have low values. In this study, the refractive index was evaluated by the following three models [34-36]. In 1985, Moss [34] found the refractive index as $n=\left(\frac{95}{E_{g}}\right)^{\frac{1}{4}}$. Later, in the same year, Hervé and Vandamme [35] introduced another approximation for the refractive index as $n=\sqrt{1+\left(\frac{13.6}{E_{g}+3.47}\right)^{2}}$, and finally, in 2010, Kumar and Singh [36] came up with the refractive index as $n=3.3668\left(E_{g}\right)^{-0.32234}$. Table 7 shows the calculated data for all these three models. In the above models, $n \approx\left(\frac{1}{E_{g}}\right)^{k}, 0.25 \leq k \leq 1$.

Table 7. Using bandgap energies, refractive indices were calculated by different methods with various $B$ concentrations

\begin{tabular}{|l|l|l|l|l|}
\hline Sample Name & Moss & $\begin{array}{l}\text { Hervé and } \\
\text { Vandamme }\end{array}$ & $\begin{array}{l}\text { Kumar and } \\
\text { Singh }\end{array}$ & $\mathrm{E}_{\mathrm{g}}(\mathrm{eV})$ \\
\hline $\mathrm{Zn}_{0.99} \mathrm{Mg}_{0.02} \mathrm{O}$ & 2.32 & 2.25 & 2.30 & 3.27 \\
\hline $\mathrm{Zn}_{0.97} \mathrm{Mg}_{0.02} \mathrm{~B}_{0.01} \mathrm{O}$ & 2.32 & 2.25 & 2.30 & 3.28 \\
\hline $\mathrm{Zn}_{0.96} \mathrm{Mg}_{0.02} \mathrm{~B}_{0.02} \mathrm{O}$ & 2.33 & 2.26 & 2.30 & 3.25 \\
\hline $\mathrm{Zn}_{0.95} \mathrm{Mg}_{0.02} \mathrm{~B}_{0.03} \mathrm{O}$ & 2.32 & 2.25 & 2.30 & 3.27 \\
\hline $\mathrm{Zn}_{0.94} \mathrm{Mg}_{0.02} \mathrm{~B}_{0.04} \mathrm{O}$ & 2.33 & 2.26 & 2.30 & 3.24 \\
\hline $\mathrm{Zn}_{0.93} \mathrm{Mg}_{0.02} \mathrm{~B}_{0.05} \mathrm{O}$ & 2.33 & 2.26 & 2.31 & 3.23 \\
\hline
\end{tabular}



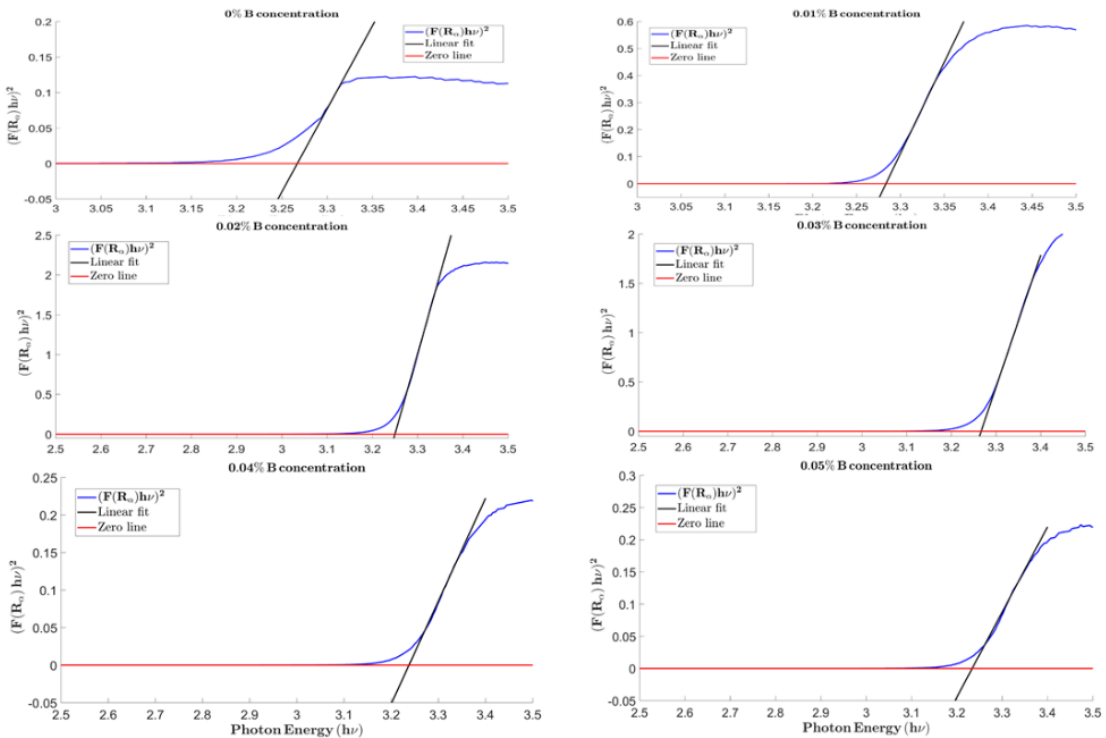

Figure 12. Left to right, top to bottom. The plots of the linear fit and $\left(F\left(R_{\alpha}\right) h v\right)^{2} v s$. photon energy $h v$ $(\mathrm{eV})$ for the $\mathrm{Zn}_{0.98-x} \mathrm{Mg}_{0.02} \mathrm{~B}_{x} \mathrm{O} \mathrm{NPs}$ ( $x=0.00$ - 0.05 with increments of 0.01)

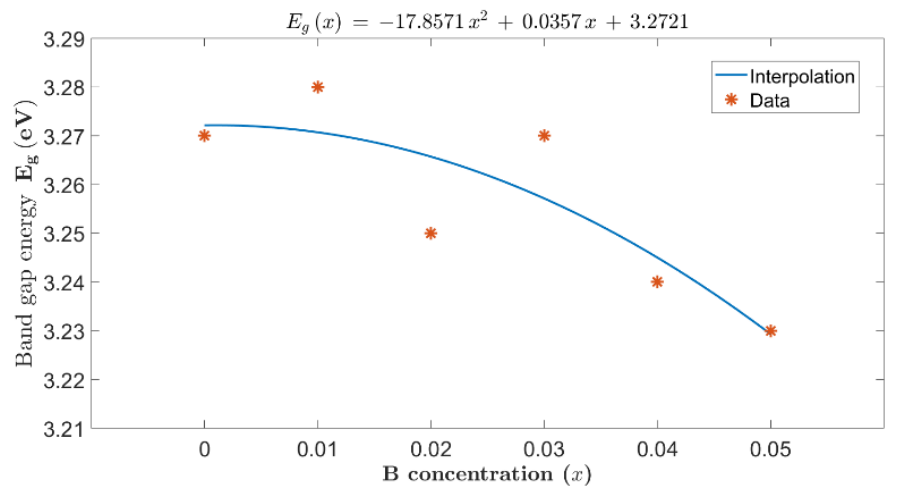

Figure 13. The polynomial fit of the bandgap energy $E_{g}(\mathrm{eV})$ vs $B$ concentration (x) for $Z n_{0.98-x} M g_{0.02} B_{x} O$ $(x=0.00-0.05$ with increments of 0.01$) \mathrm{NPS}$

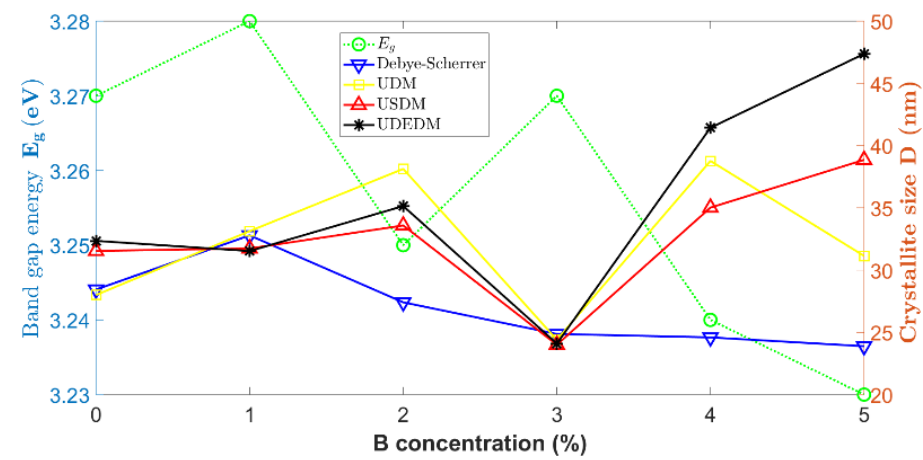

Figure 14. The crystallite size $(D)$ with the Debye-Scherrer and other Williamson-Hall methods and the bandgap energy $\left(E_{g}\right)$ for $\mathrm{Zn}_{0.98-x} \mathrm{Mg}_{0.02} B_{x} \mathrm{O}$ (x=0.00 - 0.05 with increments of 0.01) NPs 


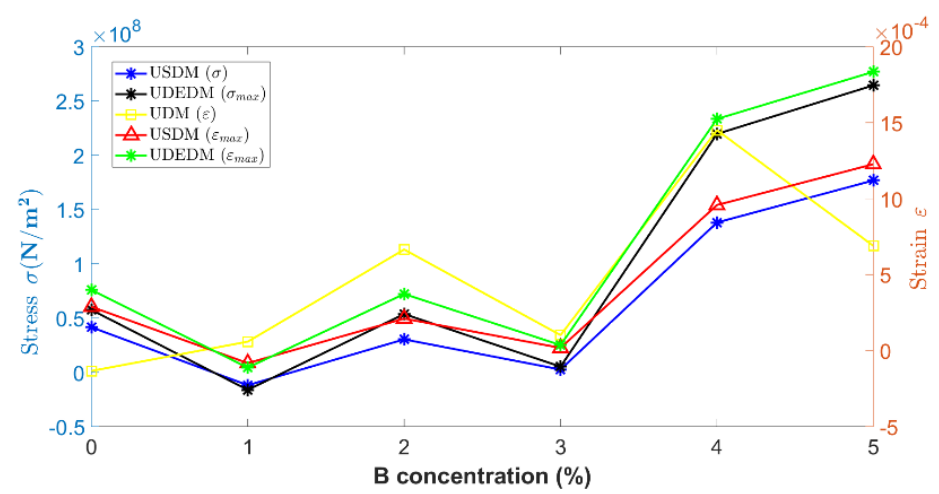

Figure 15. The stress $(\sigma)$ with the USDM and the maximum stress $(\sigma)$ with the UDEDM and the

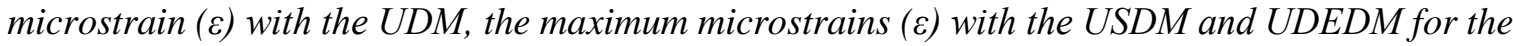
$\mathrm{Zn}_{0.98-x} \mathrm{Mg}_{0.02} \mathrm{~B}_{x} \mathrm{O}$ (x=0.00 - 0.05 with increments of 0.01) NPs

Table 7 indicates that all three models have similar patterns. Among these three models, Moss [34] gave similar results to those of Zamiri et al. [37] as shown in Table 7 for the refractive index to be in the range of $2.319-2.328$. For $3 \%$ and higher B concentrations, the refractive index increases as boron concentration increases reaching a maximum value of 2.328 at $5 \% \mathrm{~B}$ concentration as illustrated in Table 7. Tables 6 and 7 indicate energy bandgap values in the range of 3.23 to $3.28 \mathrm{eV}$, therefore our refractive index values are valid [38]. All calculated refractive indices are greater than 2 which is the desired value in applications. In addition, in 2014, Kim et al. [39] investigated the optical properties of B-doped $\mathrm{ZnO}$ particles and the bandgap energy was found to be $3.31 \mathrm{eV}$ and the refractive index in the range of 1.5 to 5 for $0-2 \% \mathrm{~B}$ concentrations. Our substance $\left(E_{g}>3 \mathrm{eV}\right.$ and $\left.n>2\right)$ reflected in this study was listed as TMs having an empty d shell according to the results of Naccarato et al. [40]. The Urbach energy $E_{u}$ is used to determine the degree of disarrangement and is playing an important role in the absorption mechanism [41]. Caglar et al. [42] stated that Urbach energy is crucial for investigating structural disorders in a thin film.

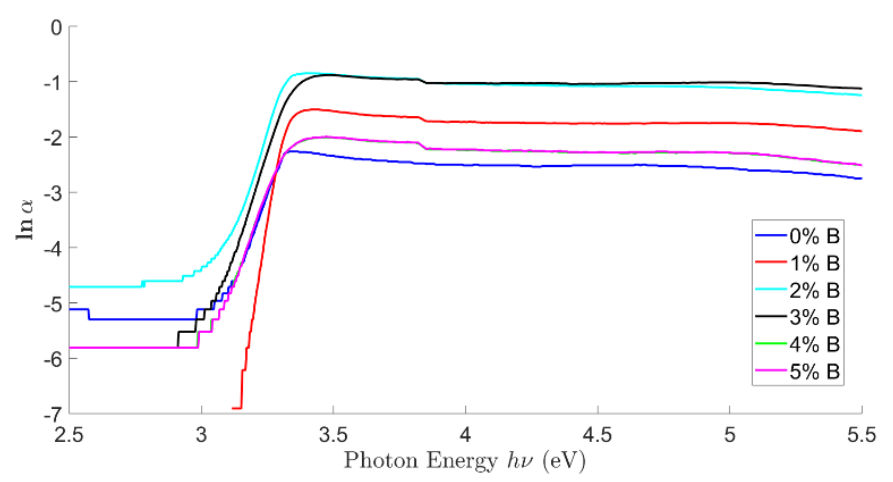

Figure 16. In $\alpha$ versus photon energy $h v(e V)$ for $\mathrm{Zn}_{0.98-x} \mathrm{Mg}_{0.02} \mathrm{~B}_{x} \mathrm{O}(x=0.00$ - 0.05 with increments of 0.01) NPS

The Urbach law is given by the relation between the Urbach energy and absorption coefficient $\alpha$ as:

$$
\alpha=\alpha_{0} e^{h v / E_{u}}
$$


where $h v$ is the photon energy and $\alpha_{0}$ is a constant term [40-41]. The following equation gives the relation between the Urbach energy values $\left(E_{u}\right)$ and the width of the localized states in bandgap [43]:

$$
E_{u}=\left[\frac{d(\ln \alpha)}{d(h v)}\right]^{-1} .
$$

For $\mathrm{Zn}_{0.98-\mathrm{x}} \mathrm{Mg}_{0.02} \mathrm{~B}_{\mathrm{x}} \mathrm{O}$ structures, Figure 16 displayed $\ln \alpha$ versus the photon energy $h v(\mathrm{eV})$. We approximated $\frac{d(\ln \alpha)}{d(h v)}$ at or nearby bandgap energy values using three finite difference methods (FDMs), namely, backward, 3-point central, and 5-point formulas with the second, second, and fourth-order accuracies, respectively. The accuracy of these FDMs is explained very well in [44]. The application of these finite difference methods can also be found in [45-46]. Figure 17(a) and Table 8 show the bandgap energy $E_{g}(\mathrm{eV})$ and Urbach energy values $E_{u}$ versus B concentration (x) of $\mathrm{Zn}_{0.98-\mathrm{x}} \mathrm{Mg}_{0.02} \mathrm{~B}_{\mathrm{x}} \mathrm{O}$ structures.

Table 8. The Urbach energy values $E_{u}$ in $\mathbf{m e V}$ calculated at $E_{g}$ by different finite difference methods (F.D.M.) for the $Z n_{0.98-x} M g_{0.02} B_{x} O$ ( $x=0.00-0.05$ with increments of 0.01) NPs

\begin{tabular}{|l|l|l|l|}
\hline $\begin{array}{l}\% \text { B } \\
\text { concentration }\end{array}$ & Backward F.D.M. & $\begin{array}{l}\text { 3-point Central } \\
\text { F.D.M. }\end{array}$ & 5-point F.D.M. \\
\hline 0 & 267.49 & 279.65 & 267.12 \\
\hline 1 & 108.91 & 120.39 & 115.90 \\
\hline 2 & 172.84 & 184.73 & 179.27 \\
\hline 3 & 260.26 & 202.85 & 214.16 \\
\hline 4 & 195.52 & 207.50 & 235.75 \\
\hline 5 & 254.78 & 266.92 & 254.40 \\
\hline
\end{tabular}

Figure 17(b) exhibits crystallite sizes $D(\mathrm{~nm})$ with the Debye-Scherrer and other Williamson-Hall methods and approximated Urbach energy $E_{u}(\mathrm{meV})$ values versus boron concentrations of $\mathrm{Zn}_{0.98-\mathrm{x}} \mathrm{Mg}_{0.02} \mathrm{~B}_{\mathrm{x}} \mathrm{O}$ structures. For undoped $\mathrm{ZnO}$ NPs synthesized by a precipitation method, $E_{u}$ was found to be $490 \mathrm{meV}$ $(0.49 \mathrm{eV})$ by Bindu and Thomas [47]. The structural disorder in the $\mathrm{Zn}_{0.98-\mathrm{x}} \mathrm{Mg}_{0.02} \mathrm{~B}_{\mathrm{x}} \mathrm{O}$ structures fluctuated with increasing concentrations of $\mathrm{B}$ in the $\mathrm{Zn}_{0.98-\mathrm{x}} \mathrm{Mg}_{0.02} \mathrm{~B}_{\mathrm{x}} \mathrm{O}$ structures which might be a sign of the increase in $E_{u}$. Table 8 shows that the lowest and highest the $E_{u}$ values are obtained in the range of 108 to $280 \mathrm{meV}$. The minimum Urbach energy value was obtained at $1 \% \mathrm{~B}$ concentration. The behavior of Urbach energy is inversely proportional to the crystallite sizes $(D)$ with the Debye-Scherrer and other Williamson-Hall methods as illustrated in Figure 17(b), demonstrating a decrement of the essential disorder [47]. The Urbach energy rises with boron substitution after 1\% boron concentration, as shown in Figure 17(a), because of the corresponding variations in the structural disorder as stated by numerous researches for zinc oxide-based films [48-50]. Moreover, the increase in the width of localized states in the bandgap is confirmed by the increase in Urbach energy and thus, responsibility for bandgap decreasing of $\mathrm{ZnMgO}$ NPs with boron substitution except at $\mathrm{x}=1 \%$ and $3 \%$.

\section{RESULTS}

The sol-gel method was used to prepare $\mathrm{Zn}_{0.98-\mathrm{x}} \mathrm{Mg}_{0.02} \mathrm{~B}_{\mathrm{x}} \mathrm{O}$ ( $\mathrm{x}=0.00$ - 0.05 with increments of 0.01 ) NPs and these NPs were annealed at $600^{\circ} \mathrm{C}$ for 30 min under ambient atmosphere. For various dopant ratios, we explored the morphological and structural properties and estimated microstrain, stress, and average crystallite size parameters by using various forms of W-H analysis, namely, the UDM, the USDM, and the UDEDM. These methods and the Scherrer formula were compared with each other. The X-ray diffraction 
illustrated that all the patterns of $\mathrm{Zn}_{0.98-\mathrm{x}} \mathrm{Mg}_{0.02} \mathrm{~B}_{\mathrm{x}} \mathrm{O}$ NPs were obtained as a $\mathrm{ZnO}$ single phase with a wurtzite hexagonal structure. The degree of distortion was found to be approximately 1 indicating that the system had no distortion. The bandgap energy was found to range between $3.23-3.28 \mathrm{eV}$ and it was inversely proportional to stress and microstrain with increasing boron concentration. As the B concentration increased, bandgap energies decreased. The lowest and highest values of Urbach energy were found to be in the range of 108 to $280 \mathrm{meV}$. The minimum dislocation density $\delta$ and Urbach energy $E_{u}$ and the maximum bandgap $E_{g}$ were obtained at $1 \% \mathrm{~B}$ concentration. This might be clarified by the fact that the stress values obtained by the USDM and UDEDM were negative, indicating compressive stress. The Urbach energy and dislocation density play a significant role in investigating structural disorders in nanoparticles. Moreover, the energy bandgap and refractive index are also two essential parameters in infrared materials and wide bandgap semiconductors.

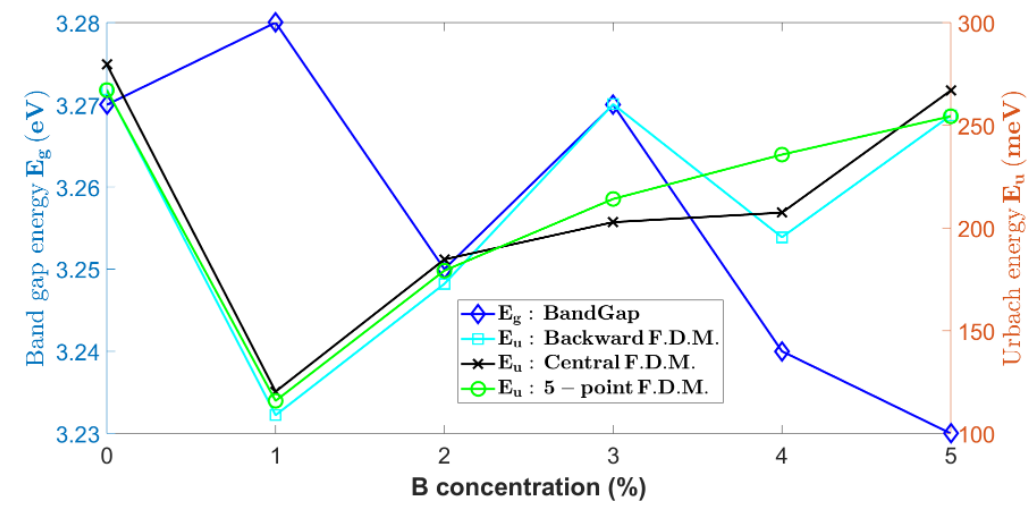

Figure 17a. The bandgap energy $E_{g}(\mathrm{eV})$ and Urbach energy $E_{u}(\mathrm{meV})$ values approximated by three different FDMs for $\mathrm{Zn}_{0.98-x} \mathrm{Mg}_{0.02} \mathrm{~B}_{x} \mathrm{O}$ (x=0.00 - 0.05 with increments of 0.01) NPs

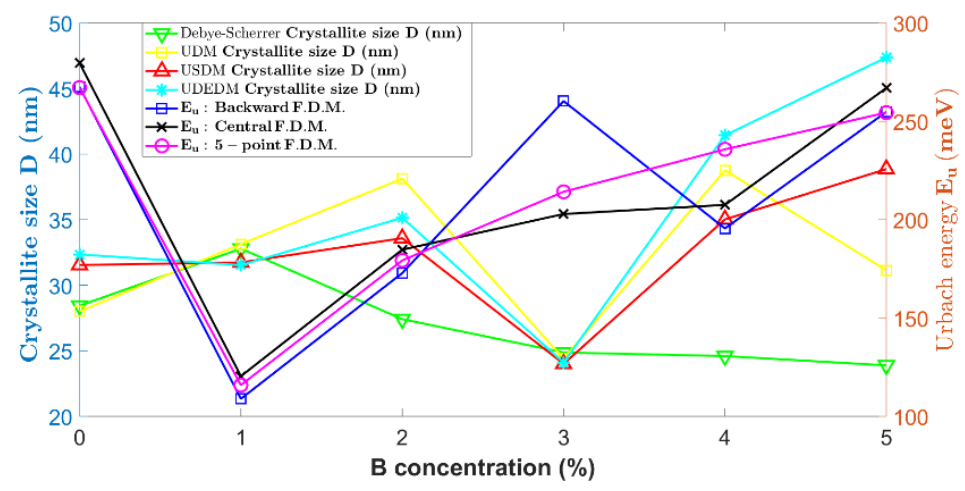

Figure 17b. The crystallite size (D) with the Debye-Scherrer and other Williamson-Hall methods and Urbach energy $E_{u}(\mathrm{meV})$ values approximated by three different FDMs for $\mathrm{Zn}_{0.98-x} \mathrm{Mg}_{0.02} \mathrm{~B}_{x} \mathrm{O}$ structures vs. boron concentration

\section{CONFLICTS OF INTEREST}

No conflict of interest was declared by the author. 


\section{REFERENCES}

[1] Hoffmann, S. P., Albert, M., Weber, N., Sievers, D., Förstner, J., Zentgraf, T., et al., "Tailored UV emission by nonlinear IR excitation from $\mathrm{ZnO}$ photonic crystal nanocavities", ACS Photonics, 5(5): 1933-1942, (2018).

[2] Khan, I., Saeed, K., Khan, I., "Nanoparticles: Properties, applications, and toxicities", Arabian J. of Chem., 12 (7): 908-931, (2019).

[3] Ronning, C., Gao, P. X., Ding, Y., Wang, Z. L., Schwen, D., "Manganese-doped ZnO nanobelts for spintronics", Appl. Phys. Lett., 84: 783-785, (2004).

[4] Ra, Y. W., Choi, K. S., Kim, J. H., Hahn, Y. B., Im, Y. H., "Fabrication of ZnO nanowires using nanoscale spacer lithography for gas sensors", Small, 4: 1105-1109, (2008).

[5] Choi, Y., Kang, J., Hwang, D., Park, S., "Electron devices, recent advances in ZnO-based lightemitting diodes", IEEE Trans. Electron Devices, 57: 26, (2010).

[6] Tang, Z. K., Wong, G. K. L., Yu, P., Kawasaki, M., Ohtomo, A., Koinuma, H., et al., "Roomtemperature ultraviolet laser emission from self-assembled $\mathrm{ZnO}$ microparticle thin films", Appl. Phys. Lett., 72(25): 3270-3272, (1998).

[7] Yurish, S. Y., “Advances in Microelectronics: Reviews”, Volume 1, Barcelona: IFSA Publishing, (2018).

[8] Vajargah, P., Abdizadeh, H., Ebrahimifard, R., Golobostanfard, M. R., "Sol-gel derived ZnO thin films: effect of amino-additives", Appl. Surf. Sci., 285: 732-743, (2013).

[9] Znaidi, L., "Sol-gel-deposited ZnO thin films: A review", Mater. Sci. and Eng. B: Solid-State Mater. for Adv. Technol., 174: 18, (2010).

[10] Noh, M. F.M., Arzaee, N. A., Safaei, J., Mohamed, N. A., Kim, H. P., Yusoff, A. R. M., et al., "Eliminating oxygen vacancies in $\mathrm{SnO} 2$ films via aerosol-assisted chemical vapor deposition for perovskite solar cells and photoelectrochemical cells”, J. Alloys Compd., 773: 997-1008, (2019).

[11] Reddy, A. J., Kokila, M. K., Nagabhushan, H., Chakradhar, R. P. S., Shivakumar, C., Rao, J. L., Nagabhushan, B. M., "Structural, optical and EPR studies on ZnO: B nanopowders prepared via low-temperature solution combustion synthesis", J. Alloys Compd., 509: 5349-5355, (2011).

[12] C`ižek, J., Valenta, J., Hruška, P., Melikhova, O., Procházka, I., Novotný, M., et al., "Origin of green luminescence in hydrothermally grown ZnO single crystals", Appl. Phys. Lett., 106: 251902, (2015).

[13] Stanić, V., "Biomedical, therapeutic and clinical applications of bioactive glasses: Boroncontaining bioactive glasses for bone regeneration", In: Kaur, G., Ed.; Woodhead Publishing: Cambridge, UK, 219-249, (2019).

[14] Duru, I. P., Ozugurlu, E., Arda, L., "Size effect on magnetic properties of $\mathrm{Zn}_{0.95-x} \mathrm{Mg}_{\mathrm{x}} \mathrm{Ni}_{0.05} \mathrm{O}$ nanoparticles by Monte Carlo simulation”, Ceram. Int., 45: 5259-5265, (2019).

[15] Senol, S. D., Boyraz, C., Ozugurlu, E., Gungor, A., Arda, L., "Bandgap Engineering of Mg Doped ZnO Nanorods Prepared by a Hydrothermal Method”, Cryst. Res. and Technol., 54 (3): 1800233, (2019). 
[16] Akcan, D., Ozharar, S., Ozugurlu, E., Arda, L., "The effects of $\mathrm{Co} / \mathrm{Cu}$ Co-doped $\mathrm{ZnO}$ thin films: An optical study", J. Alloys Compd., 797: 253-261, (2019).

[17] Ozgur, U., Alivov, Y. I., Liu, C., Teke, A., Reshchikov, M. A., Dogan, S., et al., "A comprehensive review of ZnO materials and devices", J. Appl. Phys., 98: 041301, (2005).

[18] Kim, S., Park, H., Nam, G., Yoon, H., Kim, J. Su, Kim, J. S., et al., "Temperature-dependent Photoluminescence of Boron-doped ZnO Nanorods", Bull. Korean Chem. Soc., 34 (11): 3335, (2013).

[19] Tsayn, C. Y., Hsu, W. T., "Sol-gel derived undoped and boron-doped $\mathrm{ZnO}$ semiconductor thin films: preparation and characterization”, Ceram. Int., 39: 7425-7432, (2013).

[20] Senol, S. D., Terzioglu, R., Ozturk, O., "The influence of boron doping on the structural and mechanical characterization of ZnO", J. Alloys Compd., 797: 717-726, (2019).

[21] Parra, M. R, Pandey, P., Siddiqui, H., Qadri, S. B., Haque, F. Z., "New-insight into the physical properties of $\mathrm{Zn1-xBxO}$ two dimensional hexagonal nanodisks: an efficient material for dyesensitized solar cells", Mater. Lett., 238: 194-197, (2019).

[22] Kilinc, N., Arda, L., Ozturk, S., Ozturk, Z. Z., "Structure and electrical properties of Mg-doped ZnO nanoparticles", Cryst. Res. Technol., 45(5): 529-538, (2010).

[23] Arda, L., Acikgoz, M., Heiba, Z. K., Dogan, N., Akcan, D., Cakiroglu, O., "Synthesis, characterization and ESR studies of powder $\mathrm{Zn}_{0.95-\mathrm{x}} \mathrm{Mg}_{0.05} \mathrm{Al} \mathrm{x}_{\mathrm{x}} \mathrm{O}(\mathrm{x}=0.0,0.01,0.02,0.05$, and 0.1) nanocrystals", Solid State Commun., 170: 14-18, (2013).

[24] Park, W. I., Yi, G. C., Jang, H. M., "Metalorganic vapor-phase epitaxial growth and photoluminescent properties $\mathrm{Zn}_{1-\mathrm{x}} \mathrm{Mg}_{\mathrm{x}} \mathrm{O}(0<\mathrm{x}<0.49)$ of thin films", Appl. Phys. Lett., 79 : $2022-$ 2024, (2001).

[25] Abed, C., Bouzidi, C., Elhouichet, H., Gelloz, B., Ferid, M., "Mg doping induced high structural quality of sol-gel $\mathrm{ZnO}$ nanocrystals: application in photocatalysis", Appl. Surf. Sci., 349: 855863, (2015).

[26] Guler, A., Arda, L., Dogan, N., Boyraz, C., Ozugurlu, E., "The annealing effect on microstructure and ESR properties of $(\mathrm{Cu} / \mathrm{Ni})$ co-doped $\mathrm{ZnO}$ nanoparticles", Ceram. Int., 45(2): 1737-1745, (2019).

[27] Stokes, A. R., Wilson, A. J. C., "The diffraction of x rays by distorted crystal aggregates - I.", Proc. of the Physical Soc., 56 (3): 174-181, (1944).

[28] Mote, V. D. D., Dargad, J. S. S., Purushotham, Y., Dole, B. N. N., "Effect of doping on structural, physical, morphological, and optical properties of $\mathrm{Zn}_{1-\mathrm{x}} \mathrm{Mn}_{\mathrm{x}} \mathrm{O}$ nano-particles", Ceram. Int., 41: 15153-15161, (2015).

[29] Mallika, A. N., Reddy, A. R., Babu, K. S., Sujatha, C., Reddy, K. V., "Structural and photoluminescence properties of $\mathrm{Mg}$ substituted $\mathrm{ZnO}$ nanoparticles", Opt. Mater., 36: 879-884, (2014).

[30] Pawar, B. N., Jadkar, S. R., Takwale, M. G., "Deposition and characterization of transparent and conductive sprayed ZnO: B thin films", J. Phys. Chem. Solids, 66: 1779, (2005).

[31] Kerli, S., Alver, U., Tanriverdi, A., Avar, B., "Structural and physical properties of boron-doped $\mathrm{ZnO}$ films prepared by chemical spray pyrolysis method", Crystallogr. Rep., 60: 946-950, (2015). 
[32] Bhattacharjee, S., Sarkar, P. K., Roy, A., "Polyvinyl-alcohol based devices with highly conductive, optically active boron-doped $\mathrm{ZnO}$ nanoparticles for efficient resistive-switching at ultralow operating voltage", Superlattices Microstruct., 100: 1057-1063, (2016).

[33] Hurma, T., "Effect of boron doping concentration on structural optical-electrical properties of nanostructured ZnO films", J. Mol. Struct., 1189: 1-7, (2019).

[34] Moss, T. S., "Relations between the refractive index and energy gap of semiconductors", Phys. Status Solidi B., 131: 415, (1985).

[35] Hervé, P., Vandamme, L., "General relation between refractive index and energy gap in semiconductors", Infrared Phys. Technol., 35: 609, (1994).

[36] Kumar, V., Singh, J., "Model for calculating the refractive index of different materials", Indian J. Pure Appl. Phys., 48: 571, (2010).

[37] Zamiri, R., Singh, B., Bdikin, I., Rebelo, A., Belsley, M. S., Ferreira, J., "Influence of Mg doping on dielectric and optical properties of $\mathrm{ZnO}$ nano-plates prepared by wet chemical method. Solid State Commun., 195: 74-79, (2014).

[38] Tripathy, S., "Refractive Indices of Semiconductors from Energy gaps", Opt. Mater., 46: 240246, (2015).

[39] Kim, S. H., Nam, G., Yoon, H., Kim, Y., Kim, Y., Kim, B., et al., "Optical Parameters of BoronDoped $\mathrm{ZnO}$ Nanorods Grown by Low-Temperature Hydrothermal Reaction", J. Nanosci. Nanotechnol., 14(11): 8512-8517, (2017).

[40] Naccarato, F., Ricci, F., Suntivich, J., Hautier, G., Wirtz, L., Rignanese, G. M., "Searching for materials with high refractive index and wide bandgap: A first-principles high-throughput study. Phys Rev Mater., 3: 044602, (2019).

[41] Senol, S. D., Ozugurlu, E., Arda, L., "The effect of cobalt and boron on the structural, microstructural, and optoelectronic properties of $\mathrm{ZnO}$ nanoparticles", Ceram. Inter., 46 (6): 7033-7044, (2020).

[42] Caglar, M., Ilican, S., Caglar, Y., "Influence of Dopant Concentration on the Optical Properties of ZnO: In Films by Sol-Gel Method", Thin Solid Films, 517: 5023-5028, (2009).

[43] Vettumperumal, R., Kalyanaraman, S., Santoshkumar, B., Thangavel, R., "Estimation of electronphonon coupling and Urbach energy in group-I elements doped $\mathrm{ZnO}$ nanoparticles and thin films by sol-gel method", Materials Res. Bull., 77: 101-110, (2016).

[44] LeVeque, R.J. "Finite difference methods for ordinary and partial differential equations: steadystate and time-dependent problems". Philadelphia, PA: Society for Industrial and Applied Mathematics, (2007).

[45] Ozugurlu, E., "A note on the numerical approach for the reaction-diffusion problem with a free boundary condition", ANZIAM, 51 (3): 317-330, (2010).

[46] Ozugurlu, E., "A note on the numerical approach for the reaction-diffusion problem to model the density of the tumor growth dynamics", Comput. Math. with Appl., 69 (12): 1504-1517, (2015).

[47] Bindu, P., Thomas, S., "Optical properties of $\mathrm{ZnO}$ nanoparticles synthesized from a polysaccharide and $\mathrm{ZnCl}_{2}$ ", Acta Phys. Pol A, 131: 1474-1478, (2017). 
[48] Dimova-Malinovska, D., Angelov, O., Nichev, H., Kamenova, M., Pivin, J. C., "ZnO: H thin films for room temperature selective NH3 sensors", J. Optoelectron. Adv. Mater., 9: 248, (2007).

[49] Dimova-Malinovska, D., Nichev, H., Angelov, O., Grigorov, V., Kamenova, M., "Electrical and optical properties of $\mathrm{ZnO}$ thin films prepared by magnetron rf sputtering-influence of $\mathrm{Al}$, Er, and H”, Superlattices and Microstruct., 42: 123-128, (2007).

[50] Dimova-Malinovska, D., Angelov, O., Nichev, H., Pivin, J. C., "Correlation between the stress in $\mathrm{ZnO}$ thin films and the Urbach band tail width”, J. Optoelectron. Adv. Mater., 1: 248, (2008). 